\title{
Tahap Kecerdasan Emosi Guru Pelatih Teknikal dan Vokasional di Sekolah Menengah Kejuruan (SMK)
}

\author{
Supardi*, Mohamed Nor Azhari Azman, Ramlee Mustapha, Ridzwan Che Rus, Che Ghani Che Kob \\ Jabatan Teknologi Kejuruteraan, Fakulti Pendidikan Teknikal dan Vokasional, Universiti Pendidikan Sultan Idris, 35900 Tanjung Malim, \\ Malaysia \\ *Corresponding author: pardi0186@gmail.com
}

\begin{abstract}
This study was conducted to determine the relationship between emotional intelligence (intrapersonal and interpersonal) among student teachers in Technical and Vocational Education Vocational School (SMK) Saree Aceh Besar. The sampling was done at random and a total of 35 trainees were selected as respondents. The study was conducted by using quantitative questionnaires as instruments to obtain data and further data were analyzed using descriptive and inferential statistics with the help of Statistical Package for Social Sciences. The questionnaire consists of items that assess the level of emotional intelligence. Technical statistical percentage, frequency and mean score were used to assess the level of emotional intelligence while t-test was used to test the null hypothesis. The result of descriptive analysis shows that the level of emotional intelligence respondents found the highest mean score of selfmotivation domain of 4.11. In addition, the level of emotional intelligence found significant differences by gender of the value-t 'I am good at connecting with others effectively' (D6) for the sub domain correlation capabilities to control effectively. Then the question E3 for a sub domain of social relations, the study also showed emotional intelligence by marital status found significant differences 'I can communicate well with others'. Out of the question of sub domain C1 Self motivation found significant differences 'I worked hard to get something to be desired' based on marital status. Teachers as agents of education plays an important role in the advancement of education should realize the importance of emotional intelligence in learning. With a high emotional intelligence, teachers will be able to control emotions, show more empathy and attitudes can learn to adapt to the problems encountered and can provide a good education to the students emotionally.
\end{abstract}

Keywords: Emotional Quotient (EQ); technical and vocational trainees

\begin{abstract}
Abstrak
Kajian ini dijalankan bagi mengenalpasti hubungan kecerdasan emosi (intrapersonal dan interpersonal) dalam kalangan guru pelatih Teknik dan Vokasional di Sekolah Menengah Kejuruan (SMK) Saree Aceh Besar. Pemilihan sampel secara rawak mudah telah dilakukan dan seramai 35 orang guru pelatih telah dipilih sebagai responden. Kajian ini dilakukan secara kuantitatif dengan menggunakan borang soal selidik sebagai instrumen untuk mendapatkan data dan seterusnya data yang diperoleh dianalisis dengan menggunakan statistik deskriptif dan inferensi dengan bantuan Statistical Packages for Social Sciences. Soal selidik yang dibentuk mengandungi item yang mengukur tahap kecerdasan emosi. Teknikal statistik pemeratusan, kekerapan dan min skor digunakan bagi mengukur tahap kecerdasan emosi manakala ujian-t digunakan bagi menguji hipotesis nol. Dapatan analisis deskriptif menunjukkan bahawa tahap kecerdasan emosi responden didapati nilai skor min tertinggi daripada domain motivasi kendiri iaitu sebanyak 4.11. Selain itu, tahap kecerdasan emosi didapati perbezaan yang signifikan mengikut jantina daripada nilai-t 'saya mahir berhubung dengan orang lain dengan berkesan' (D6) bagi sub domain keupayaan mengendalikan hubungan yang berkesan. Kemudian daripada soalan E3 bagi sub domain perhubungan sosial, dapatan kajian juga menunjukkan kecerdasan emosi mengikut taraf perkahwinan yang didapati terdapat perbezaan yang signifikan 'saya boleh berkomunikasi dengan baik dengan orang lain'. Daripada soalan C1 dari sub domain motivasi kendiri didapati perbezaan yang signifikan 'saya berusaha bersungguh-sungguh untuk mendapatkan sesuatu yang diinginkan' berdasarkan taraf perkahwinan. Guru sebagai ejen pendidikan yang berperanan penting dalam kemajuan pendidikan harus menyedari bahawa kepentingan kecerdasan emosi dalam pembelajaran. Dengan adanya kecerdasan emosi yang tinggi, guru akan berupaya mengawal emosi, menunjukkan sikap lebih berempati dan dapat belajar menyesuaikan diri dengan masalah yang dihadapi serta dapat memberikan pendidikan emosi yang baik kepada pelajar.
\end{abstract}

Kata kunci: Kecerdasan Emosi (EQ); guru pelatih teknikal dan vokasional

(C) 2016 Penerbit UTM Press. All rights reserved 


\subsection{PENGENALAN}

Perkataan emosi adalah berasal dari perkataan Greek iaitu emover yang bermaksud "untuk keluar". Emosi dipamerkan oleh setiap individu dalam bentuk tindakan dengan tujuan untuk memenuhi kepuasan diri individu itu sendiri dan ia boleh dikatakan sebagai satu keadaan di mana perasaan yang ditunjukkan pada proses fisiologi dan psikologi seseorang individu itu. Ia adalah merupakan satu set tindak balas automatik, visceral dan komunikasi emosi seperti ekspresi muka, perkataan, tingkahlaku dan isyarat yang dipamerkan oleh individu itu (Mahmood Nazar, 1990).

Menurut Goleman (1995), kecerdasan emosi (EQ) adalah kebolehan untuk mengawasi emosi diri dan emosi pihak lain, dapat membezakan kebaikan, dan dapat menggunakan maklumat untuk membantu fikiran dan tindakan seseorang. Kecerdasan emosi juga boleh didefinisikan sebagai sejenis kecerdasan sosial yang dapat mengawal pelbagai emosi, untuk mendiskriminasikan emosi tersebut dan menggunakan maklumat untuk mengawal pemikiran dan tindakan (Mayer \& Salovey, 1993). Berdasarkan pendapat Goleman (1995), kecerdasan emosi interpersonal dan intrapersonal dapat dikategorikan kepada lima (5) domain utama iaitu (1) mengenal diri, (2) mengurus emosi kendiri, (3) memotivasikan diri, (4) empati dan (5) mengendalikan hubungan yang berkesan. Empati dan mengendalikan hubungan yang berkesan adalah dikategorikan dalam kecerdasan interpersonal sementara tiga lagi iaitu mengenal diri, mengurus emosi dan memotivasikan diri adalah di dalam kategori intrapersonal.

Thorndike (1920) pula berpendapat bahawa kecerdasan emosi manusia adalah berkaitan dengan konsep kecerdasan sosial. Ahli-ahli psikologi lain telah membahagikannya kepada tiga fasa. Pertama, kecerdasan abstrak iaitu kebolehan untuk memahami dan memanipulasi tindakbalas dan simbol matematik. Kedua, kecerdasan yang konkrit iaitu kebolehan untuk memahami dan memanipulasi objek dan yang ketiga adalah kecerdasan sosial iaitu kebolehan untuk memahami dan berhubung dengan manusia (Ruisel, 1992). Guru adalah insan yang cukup istimewa lantaran tanggungjawab dan amanah yang terpaksa dipikul untuk mendidik manusia menjadi insan yang berperibadi mulia, berakhlak tinggi dan kamil (Fletcher, 2007). Guru merupakan role-model, oleh itu sudah semestinya guru menunjukkan contoh yang baik dan mereka haruslah mempunyai kecerdasan emosi yang tinggi. Dalam perspektif kehidupan hari ini, kecerdasan emosi dilihat mempunyai peranan yang besar dalam bidang pendidikan, bukan sahaja mementingkan kepada kecerdasan mental tetapi juga meliputi aspek kecerdasan emosi. Kecerdasan emosi menjadi pendukung kepada kecerdasan mental dan menjamin kualiti produk yang dihasilkan (Mohd Azhar, 2006). Cabaran itu turut dirasai oleh guru-guru pelatih teknikal dan vokasional disekolah menengah kejuruan (SMK) Aceh Besar. Harmain (2008) menyatakan 60\% - 70\% guru belum dapat melaksanakan tugasnya dengan baik. Faktanya guru sering meninggalkan tugas wajib untuk mengajar, tidak hadir tepat pada permulaan jam pelajaran dan keluar sebelum jam pelajaran selesai. Target garis besar program pengajaran yang belum dipenuhi, tidak memberikan contoh yang baik dan belum mampu memberikan situasi belajar yang kondusif kerana kurang persiapan mengajar. Guru dalam melaksanakan interaksi edukatif masih banyak menggunakan kata-kata negatif, seperti, melarang dengan membentak, memperolok dan marah secara berlebihan. Perilaku guru tersebut tidak mencerminkan prestasi sesuai standard yang ditetapkan.

Guru merupakan sumber tenaga manusia terpenting dalam pendidikan (Ahmad Shaufie, 2004). Jika sumber tenaga ini tidak diuruskan secara bijak, banyak permasalahan akan timbul. Sejak kebelakangan ini, kemerosotan kecerdasan emosi dalam kalangan guru semakin ketara (Ahmad Shaufie, 2004). Profesion sebagai guru mempunyai pelbagai cabaran dan liku-liku yang perlu ditempuhi sepanjang berada di sekolah. Masrikin (2006) menyatakan bahawa prestasi kerja yang dicapai dan proses dalam melaksanakan tugas dan tanggung jawab sesuai dengan standard yang telah ditentukan. Prestasi guru harus sesuai dengan standard yang telah dipersetujui, serta terlaksananya tugas dan tanggung jawab sesuai dengan kod etika guru. Dalam kajian ini, objektif adalah untuk mengkaji tahap kecerdasan emosi (Intrapersonal dan Interpersonal) dalam kalangan guru pelatih Teknikal Vokasional dan mengenalpasti perbezaan kecerdasan emosi (Intrapersonal dan Interpersonal) guru pelatih Teknikal Vokasional berdasarkan faktor demografi yang terpilih.

\subsection{SOROTAN LITERATUR}

\subsection{Kajian Lepas}

Berdasarkan kajian-kajian yang terdapat pada Jadual 1 perbandingan kajian yang berkaitan dengan kecerdasan emosi, kajian ini telah menyokong pengkaji untuk mendapatkan maklumat yang diperlukan bagi kajian ini.Kajian lepas ini didapati sebanyak 15 kajian untuk membandingkan dengan teoritikal yang menyokong dalam melakukan penyelidikan oleh pengkaji untuk mengetahui faktor-faktor yang mempengaruhi tahap kecerdasan emosi guru.

Menurut Goleman (1995), penilaian seseorang individu bukan sahaja diasaskan kepada kecerdasan yang ada pada keintelektualannya (IQ) sahaja tetapi yang lebih penting adalah kecerdasan emosi (EQ) yang ada pada dirinya. Goleman (1995) juga menyatakan bahawa kecerdasan otak atau IQ hanya menyumbangkan sebanyak 20\% dalam menentukan kejayaan hidup. Manakala $80 \%$ kejayaan adalah ditentukan oleh faktor EQ. Goleman juga menyimpulkan bahawa tahap IQ yang tinggi mungkin berkait rapat dengan kejayaan akademik di universiti tetapi prestasi mereka dalam pekerjaan belum pasti lagi.Berkemungkinan ianya berkait rapat dengan tahap EQ mereka. Dengan itu, EQ dikatakan boleh menentukan masa hadapan individu.

Mayer dan Salovey pada tahun 1990 telah membawa dimensi baru dalam penilaian pendidikan dengan memperkenalkan istilah kecerdasan emosi (EQ) kepada dunia. Ini menyebabkan ramai pakar mengatakan kegiatan manusia tidak hanya bergantung kepada kecerdasan intelek (IQ) seseorang dan keputusan yang mereka buat dalam banyak perkara juga bergantung kepada EQ. Secara umumnya, EQ boleh dibahagikan kepada dua bahagian utama, iaitu emosi perhubungan kendiri (Intrapersonal) dan emosi untuk perhubungan dengan orang lain (Intrapersonal). Intrapersonal boleh dibahagikan kepada tiga kategori, iaitu mengenal emosi kendiri, mengurus emosi kendiri dan memotivasikan emosi kendiri. Manakala Intrapersonal pula boleh dipecahkan kepada dua kategori, iaitu mengendalikan perhubungan yang berkesan dan mengenal emosi orang lain (Mohd Najib et al., 2002) Sementara itu, menurut Bar-On (2000), kecerdasan emosi adalah suatu rangkaian emosi, pengetahuan emosi dan kemampuan-kemampuan yang mempengaruhi kemampuan keseluruhan individu untuk mengatasi masalah tuntutan lingkungan secara efektif. 
Jadual 1 Perbandingan kajian

\begin{tabular}{|c|c|c|c|c|}
\hline $\begin{array}{l}\mathbf{B I} \\
\mathbf{L}\end{array}$ & TAJUK & PEMBOLEHUBAH & 䒺离 & 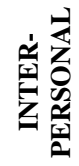 \\
\hline 1. & $\begin{array}{l}\text { Hubungan di antara kecerdasan emosi dengan kepimpinan bakal } \\
\text { guru dikalangan pelajar.(Wan Mat, 2004) }\end{array}$ & $\begin{array}{l}\text { - Kekerapan } \\
\text { - Kesadaran diri } \\
\text { - Kemahiran sosial }\end{array}$ & $\begin{array}{l}\sqrt{ } \\
\sqrt{ }\end{array}$ & $\sqrt{ }$ \\
\hline 2. & $\begin{array}{l}\text { Pengaruh kecerdasan emosional terhadap penyesuaian sosial siswa } \\
\text { di sekolah (Nurdin, 2009) }\end{array}$ & $\begin{array}{l}\text { Kemampuan } \\
\text { mengendalikan diri } \\
\text { - Semangat dan kesabaran } \\
\text { - Ketekunan dan } \\
\text { Keterampilan sosial } \\
\end{array}$ & $\begin{array}{l}\sqrt{ } \\
\sqrt{ } \\
\sqrt{ }\end{array}$ & \\
\hline 3. & $\begin{array}{l}\text { Kecerdasan emosi dan komitmen pekerjaan dalam kalangan } \\
\text { pensyarah Universiti di Indonesia (Zuria Mahmud, 2009) }\end{array}$ & $\begin{array}{l}\text { - Motivasi kendiri } \\
\text { - Regulasi kendiri } \\
\text { - Kesedaran kendiri } \\
\text { - Kemahiran sosial }\end{array}$ & $\begin{array}{l}\sqrt{ } \\
\sqrt{ } \\
\sqrt{ }\end{array}$ & $\sqrt{ }$ \\
\hline 4. & $\begin{array}{l}\text { Profil kecerdasan emosi guru pelatih bahasa mengikut tahun } \\
\text { pengajian (Yunus, 2010) }\end{array}$ & $\begin{array}{l}\text { - Segi kesedaran kendiri } \\
\text { - Regulasi kendiri } \\
\text { - Motivasi kendiri } \\
\text { - Empati kemahiran sosial }\end{array}$ & $\begin{array}{l}\sqrt{ } \\
\sqrt{ } \\
\sqrt{ }\end{array}$ & $\sqrt{ }$ \\
\hline 5. & $\begin{array}{l}\text { Profil kecerdasan emosi guru-guru sekolah menengah Zon Tengah } \\
\text { Semenanjung Malaysia (Ishak, 2010) }\end{array}$ & $\begin{array}{l}\text { Mengendalikan hubungan } \\
\text { sosial } \\
\text { - Pengawalan kendiri } \\
\text { - Terendah pada domain } \\
\text { - kemahiran sosial. }\end{array}$ & $\sqrt{ }$ & $\sqrt{ }$ \\
\hline 6. & $\begin{array}{l}\text { Hubungan kecerdasan emosi dengan kecekapan kemahiran dan } \\
\text { perkembangan personal dalam kalangan guru-guru kaunseling } \\
\text { daerah kulaijaya, Johor (M. Nasir, 2011) }\end{array}$ & $\begin{array}{l}\text { - Kesedaran kendiri } \\
\text { - Pengawalan kendiri } \\
\text { - Motivasi kendiri } \\
\text { - Kemahiran sosial }\end{array}$ & $\begin{array}{l}\sqrt{ } \\
\sqrt{ } \\
\sqrt{ }\end{array}$ & $\sqrt{ }$ \\
\hline 7. & $\begin{array}{l}\text { Persepsi guru terhadap tahap kecerdasan emosi pengetua dan } \\
\text { hubungannya dengan motivasi kerja guru (Mohd Zuri, 2011) }\end{array}$ & $\begin{array}{l}\text { - Motivasi kendiri } \\
\text { - Kecerdasan emosi } \\
\text { - Kemahiran sosial }\end{array}$ & $\sqrt{ }$ & $\begin{array}{l}\sqrt{ } \\
\sqrt{ }\end{array}$ \\
\hline 8. & $\begin{array}{l}\text { Tahap kecerdasan emosi dan hubungannya dengan komitmen guru } \\
\text { dalam bekerja dalam kalangan guru mata pelajaran teras tahun } \\
\text { enam (Yusof Boon, 2011) }\end{array}$ & $\begin{array}{l}\text { Motivasi kendiri } \\
\text { - Mengenal emosi kendiri } \\
\text { - Dimensi kemahiran sosial } \\
\text { - Kesendaran kendiri dan } \\
\text { - Dimensi kawalan kendiri }\end{array}$ & $\begin{array}{l}\sqrt{ } \\
\sqrt{ } \\
\sqrt{ } \\
\sqrt{ }\end{array}$ & $\sqrt{ }$ \\
\hline 9. & $\begin{array}{l}\text { Kecerdasan emosi dan hubungan dengan perilaku dan prestasi } \\
\text { akademik pelajar sekolah menengah (Rodziah, 2012) }\end{array}$ & $\begin{array}{l}\text { - Kesedaran kendiri } \\
\text { - Kawalan kendiri } \\
\text { - Motivasi empati dan } \\
\text { - Kemahiran sosial }\end{array}$ & $\begin{array}{l}\sqrt{ } \\
\sqrt{ } \\
\sqrt{ }\end{array}$ & $\sqrt{ }$ \\
\hline 10. & $\begin{array}{l}\text { Persepsi guru-guru bidang teknik dan vokasional Sekolah } \\
\text { Menengah Kebangsaan Tinggi Segamat dalam meningkatkan } \\
\text { kecerdasan emosi pelajar: satu kajian kes kualitatif (Hisyam, 2012) }\end{array}$ & $\begin{array}{l}\text { Ekonomi rumah tangga } \\
\text { - Perdangan dan ekonomi asas } \\
\text { - Mengendalikan hubungan sosial }\end{array}$ & & $\begin{array}{l}\sqrt{ } \\
\sqrt{ } \\
\sqrt{ }\end{array}$ \\
\hline 11. & $\begin{array}{llll}\text { Pengembangan } & \text { model bimbingan kelompok dengan } & \text { teknik } \\
\text { simulasi untuk } & \text { meningkatkan kecerdasan emosi siswa } & \text { (Indah } \\
\text { lestari, 2012) } & & \end{array}$ & $\begin{array}{l}\text { - Motivasi kendiri } \\
\text { - Regulasi kendiri } \\
\text { - Kesedaran kendiri } \\
\text { - Kemahiran sosial }\end{array}$ & $\begin{array}{l}\sqrt{ } \\
\sqrt{ } \\
\sqrt{ }\end{array}$ & $\sqrt{ }$ \\
\hline 12. & $\begin{array}{l}\text { Penentuan jangkaan kerjaya, kecerdasan emosi dan kompetensi } \\
\text { profesional terhadap prestasi guru SMP Se-Kecamatan Blahbatuh } \\
\text { (Wedastera } \text { et al. , 2013) }\end{array}$ & $\begin{array}{l}\text { - Kemampuan mengenali emosi kendiri } \\
\text { - Kemampuan mengelola emosi } \\
\text { - Kemampuan memotivasi diri } \\
\text { - Kemampuan mengenali emosi orang lain } \\
\text { - Kemampuan membina hubungan sosial }\end{array}$ & $\begin{array}{l}\sqrt{ } \\
\sqrt{ } \\
\sqrt{ } \\
\sqrt{ }\end{array}$ & $\sqrt{ }$ \\
\hline 13. & $\begin{array}{l}\text { Kecerdasan emosi dalam kalangan guru sekolah menengah teknik } \\
\text { kementerian pendidikan malaysia berdasarkan Model Dulewicz } \\
\text { dan Higg's (Ahmad, 2013) }\end{array}$ & $\begin{array}{l}\text { - Kesedaran diri } \\
\text { - Motivasi } \\
\text { - Ketahanan emosi }\end{array}$ & $\begin{array}{l}\sqrt{ } \\
\sqrt{ } \\
\sqrt{ }\end{array}$ & \\
\hline 14. & $\begin{array}{l}\text { Peranan kecerdasan emosi dan faktor ciri-ciri pekerjaan ke atas } \\
\text { kepuasan bekerja dalam profesion perguruan (Rohany Nasi, 2013) }\end{array}$ & $\begin{array}{l}\text { - Dimensi mengenali emosi diri } \\
\text { - Pengurusan emosi } \\
\text { - Kecekapan sosial dan kemahiran sosial }\end{array}$ & $\begin{array}{l}\sqrt{ } \\
\sqrt{ }\end{array}$ & $\sqrt{ }$ \\
\hline 15. & $\begin{array}{l}\text { Upaya peningkatan kecerdasan emosi siswa sekolah dasar Melalui } \\
\text { pendidikan jasmani harmoni, (Rustiana, 2013) }\end{array}$ & $\begin{array}{l}\text { - Kesadaran kendiri } \\
\text { - Penghargaan kendiri } \\
\text { - Berdikari kendiri } \\
\text { - Tanggungjawab sosial }\end{array}$ & $\begin{array}{l}\sqrt{ } \\
\sqrt{ } \\
\sqrt{ }\end{array}$ & $\sqrt{ }$ \\
\hline
\end{tabular}

Menurut Najib (2002) Seorang guru yang melihat kritikan sebagai suatu rangsangan positif tidak akan cepat marah kepada murid atau guru serta ketua dan ini boleh membantu meningkatkan martabat profesion guru itu sendiri. Secara ringkasnya, keupayaan mengenal 
emosi orang lain akan meningkatkan tahap kecerdasan emosi kita. Kriteria kecerdasan emosi yang diterangkan boleh dijelaskan seperti dalam Rajah 1.

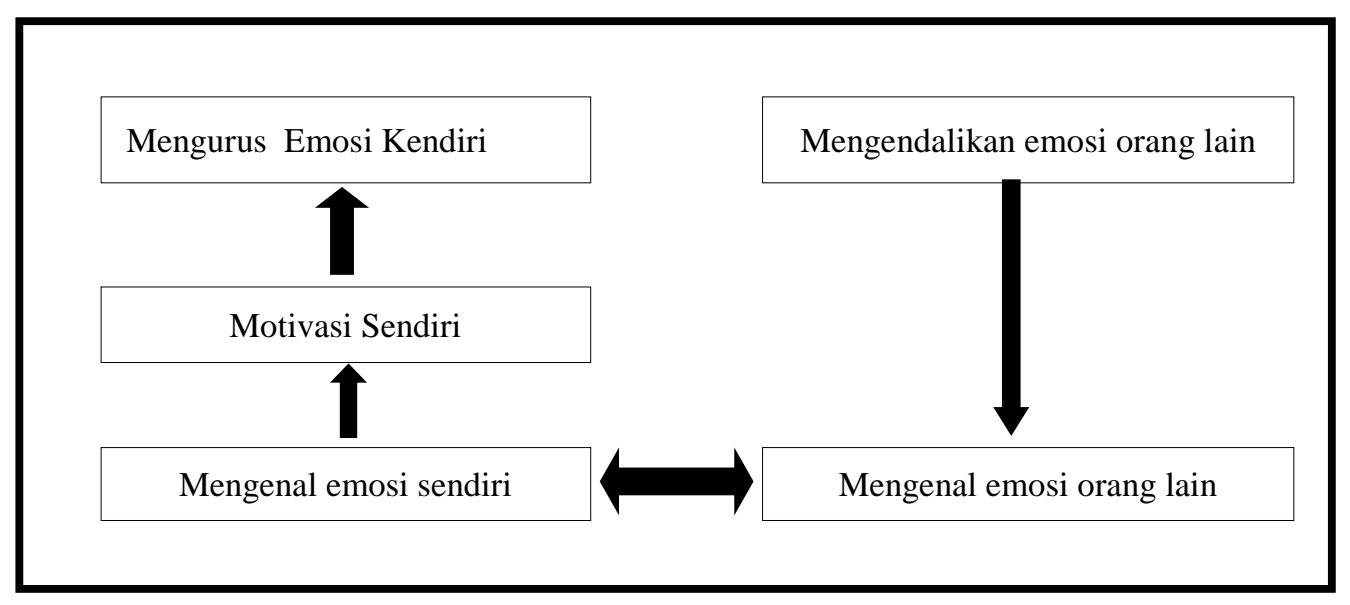

Rajah 1 Aliran ciri kecerdasan emosi

\subsection{METODOLOGI KAJIAN}

Kajian ini dijalankan berbentuk kajian kuantitatif di mana jenis soal selidik bertujuan untuk mendapatkan maklumat yang tepat dan berkesan. Responden dapat memberikan tindakbalas dengan baik aspek yang ingin dikaji berbanding dengan kaedah temubual. Seramai 35 orang guru Sekolah Menengah Kejuruan (SMK) Saree telah dipilih secara subjek kajian. Guru-guru pelatih ini terdiri daripada pelbagai latar belakang yang berbeza dari segi jantina, umur pengalaman mengajar, taraf pendidikan dan taraf perkahwinan.

\section{Pengumpulan Data}

Pengumpulan data dijalankan dengan menggunakan instrumen soal selidik. Instrumen soal selidik digunakan oleh penyelidik bagi mendapatakan maklumat berkenaan dengan fakta-fakta, kepercayaan, perasaan kehendak dan sebagainya di dalam sesuatu kajian (Mohd Najib, 1990).

\section{Instrumen}

Mohd Najib (1998) menyatakan bahawa instrumen adalah alat untuk menentukan jenis data yang diperolehi dan ini akan mempengaruhi jenis analisis data. Instrumen yang digunakan dalam kajian ini adalah jenis soal selidik kerana bertujuan untuk mendapatkan maklumat yang tepat dan berkesan seperti dalam Jadual 2.

Jadual 2 Instrumen kecerdasan emosi (EQ)

\begin{tabular}{cccc}
\hline Konstruk & Kategori & No Item & Jumlah Item \\
\hline \multirow{2}{*}{ Intrapersonal } & Keupayaan mengenal emosi kendiri & $1,2,3,4,5,6,7,8,9$ & 9 \\
\cline { 2 - 4 } & Keupayaan mengurus emosi kendiri & $10,11,12,13,14,15,16,17$ & 8 \\
\cline { 2 - 4 } & Motivasi kendiri & $18,19,20,21,22,23$ & 6 \\
\hline \multirow{2}{*}{ Interpersonal } & Keupayaan mengendalikan hubungan yang berkesan & $24,25,26,27,28,29,30,31,32,33,34,35$ & 12 \\
\cline { 2 - 4 } & Keupayaan mengenal emosi orang lain & $36,37,38,39,40,41,42,43,44,45$ & 10 \\
\hline
\end{tabular}

Alat ukur menguji EQ di mana ia dikategorikan kepada dua konstruk utama iaitu intrapersonal dan interpersonal. Terdapat lima kategori iaitu mengenal emosi kendiri, mengurus emosi kendiri, memotivasikan emosi kendiri, mengendalikan perhubungan yang berkesan dan mengendalikan emosi orang lain. Bagi setiap penyataan responden diberi pilihan jawapan mengikut Skala Likert (Jadual 3) dan interpretasi julat min (Jadual 4).

Jadual 3 Skala Likert

\begin{tabular}{ccc}
\hline Penjelasan & & Nilai \\
\hline Sangat tidak setuju & & 1 \\
Tidak setuju & & 2 \\
Tidak pasti & & 3 \\
Setuju & & 4 \\
\hline Sangat setuju & & 5 \\
\hline
\end{tabular}

Sumber : Mohammad Najib (2000) 
Jadual 4 Interpretasi julat min

\begin{tabular}{cc}
\hline Skor Min & Penjelasan \\
\hline $1.00-1.80$ & Sangat tidak setuju \\
$1.81-2.60$ & Tidak setuju \\
$2.61-3.40$ & Tidak pasti \\
$3.41-4.20$ & Setuju \\
$4.21-5.00$ & Sangat setuju \\
\hline Sumber : Mohamad Najib (2000)
\end{tabular}

Sumber : Mohamad Najib (2000)

\section{Kesahan dan Kebolehpercayaan}

Kesahan dan kebolehpercayaan alat kajian penting dalam sesuatu kajian. Kesahan atau kesahihan merupakan satu konsep yang merujuk kepada sejauh mana alat kajian mengukur apa yang hendak diukur atau sejauh mana alat kajian itu menepati tugasnya (Anastasi dan Urbina, 1997). Menurut Murphy dan Davidshofer (1988), APA Standards for Psychology Test (1954) telah mengenal pasti empat strategi untuk mengukur kesahan yang melibatkan kesahan kandungan, kesahan konstruk, kesahan ramalan dan kesahan serentak. Pengkaji menggunakan pekali Alpha Cronbach untuk menganggarkan pekali ketekalan dalaman soal selidik yang mengukur kecerdasan emosi. Berdasarkan analisis data, nilai pekali kebolepercayaan bagi kecerdasan emosi $\alpha=0.75$, di mana pada tahap yang sangat baik. Mohd Majid (1998), menyatakan bahawa indeks kebolehpercayaan yang boleh digunakan hendaklah sekurang-kurangnya mempunyai nilai $\alpha=0.60$ atau lebih. Berdasarkan kenyataan ini, maka indeks kebolepercayaan alat ukuran kajian ini adalah baik.

\section{Kajian Rintis}

Kajian rintis dijalankan bertujuan untuk menguji kesahan dan ketekalan dalaman instrumen yang digunakan. Polit et al. (2001) menyatakan bahawa kajian rintis adalah merujuk kepada kajian kecil atau percubaan yang dilakukan sebagai persediaan sebelum melakukan kajian yang lebih besar. Selain itu, kajian rintis juga dijalankan bertujuan untuk menguji dan mengetahui tahap kefahaman responden terhadap item-item soalan yang dikemukakan. Seramai empat (4) orang responden terlibat dalam kajian rintis. Melalui kajian tersebut, didapati tidak terdapat sebarang masalah yang dikemukakan oleh responden terhadap item-item yang terdapat pada soalan kaji selidik tersebut dan ini menunjukkan bahawa item-item yang dikemukakan dalam soal kaji selidik tersebut adalah baik untuk tujuan penyelidikan.

\subsection{DAPATAN KAJIAN}

\section{Profil Responden}

Kajian ini melibatkan seramai 35 guru pelatih sekolah menengah teknikal dan vokasional di Saree Aceh Besar. Jadual 5 menunjukkan bahawa seramai 17 orang (48.6\%) guru lelaki dan 18 orang guru (51.4\%) perempuan. Taburan responden berdasarkan taraf perkahwinan juga menunjukkan jumlah responden belum berkahwin sebanyak 18 orang (51.4\%) guru. Manakala yang sudah berkahwin sebanyak 17 orang $(48.6 \%)$ guru. Oleh demikian, dapatan kajian juga menunjukkan bahawa sebanyak $17.1 \%$ guru berumur $20-24$ tahun, $40.0 \%$ guru berumur 25-29 tahun. Seterusnya, 17.1\% guru berumur 30 -34 tahun, pada tahap umur 35-39 tahun didapati 11.4\%. Kemudian tahap umur 40 - 44 tahun $8.6 \%$ guru dan tahap umur 45 ke atas dalam kajian ini didapati paling sedikit iaitu sebanyak $5.7 \%$ guru. Jadual 4 menunjukkan taburan responden berdasarkan umur guru. Dapatan kajian menunjukkan bahawa 20.0\% guru berpengalaman mengajar lima (5) tahun kebawah, $14.3 \%$ orang guru berpengalaman mengajar 5 - 10 tahun, 31.4\% orang guru berpengalaman mengajar 10 - 15 tahun, manakala $34.3 \%$ orang berpengalaman mengajar 15 - 20 tahun. Dari segi taraf pendidikan guru menunjukkan $14.3 \%$ orang guru memiliki taraf pendidikan diploma, manakala dapatan kajian menunjukkan bahawa 29 orang guru memiliki taraf pendidikan sarjana muda iaitu yang paling banyak daripada taraf pendidikan lainnya, dan hanya 1 orang daripada guru memiliki taraf pendidikan di peringkat sarjana.

Jadual 5 Taburan responden berdasarkan profil responden

\begin{tabular}{llcc}
\hline \multicolumn{1}{c}{ Butiran } & & Kekerapan $(\boldsymbol{f})$ & Peratus $(\%)$ \\
\hline \multirow{2}{*}{ Jantina } & Lelaki & 17 & 48.6 \\
& Perempuan & 18 & 51.4 \\
\hline \multirow{2}{*}{ Taraf Perkahwinan } & Belum kahwin & 18 & 51.4 \\
& Berkahwin & 17 & 48.6 \\
& $20-24$ tahun & 6 & 17.1 \\
& $25-29$ tahun & 14 & 40.0 \\
Umur & $30-34$ tahun & 6 & 17.1 \\
& $35-39$ tahun & 4 & 11.4 \\
& $40-44$ tahun & 3 & 8.6 \\
\multirow{2}{*}{ Pengalaman Mengajar } & 45 tahun keatas & 2 & 5.7 \\
& 5 tahun Ke Bawah & 7 & 20.0 \\
& $5-10$ tahun & 5 & 14.3 \\
Taraf Pendidikan & $10-15$ tahun & 11 & 31.4 \\
& $15-20$ tahun & 12 & 34.3 \\
\hline Jumlah & Diploma & 5 & 14.3 \\
& Sarjana muda & 29 & 82.9 \\
\end{tabular}




\section{Kecerdasan Emosi Responden Sekolah Menengah Kejuruan}

Bahagian ini adalah untuk menjawab persoalan kajian mengenai lima (5) domain kecerdasan emosi iaitu domain keupayaan mengenal emosi kendiri, domain keupayaan mengurus emosi, domain motivasi kendiri, domain keupayaan mengendalikan hubungan yang berkesan serta domain perhubungan sosial.

\section{Keupayaan Mengenal Emosi Kendiri (Self-awareness)}

Hasil dapatan pada item-item dalam domain keupayaan mengenal emosi kendiri ini, didapati skor min tertinggi pada item tujuh (7) di mana majoriti responden memilih bersetuju bahawa mereka memiliki keupayaan memahami maklumat yang dapat mempengaruhi diri mereka sehingga skor nilai min yang didapati tinggi daripada responden yang memilih skala skor min pada item lainnya. Manakala item empat (4) menunjukkan bahawa skor min terendah berbanding dengan item-item lainya. Item empat (4) tersebut menunjukkan bahawa majoriti responden mereka memilih tidak pasti samada mereka akan bercakap pada diri sendiri bila perlu untuk mengendalikan emosi diri rujuk Jadual 6.

Jadual 6 Taburan min dan sisihan piawai bagi sub domain keupayaan mengenal emosi kendiri

\begin{tabular}{llcc}
\hline & \multicolumn{1}{c}{ Item } & Min (M) & Sisihan Piawai (SP) \\
\hline 1. & Saya mengenali perubahan psikologi yang berlaku pada diri saya & 3.91 & 0.78 \\
2. & Perubahan pada persekitaran akan mempengaruhi perubahan emosi saya & 3.83 & 1.04 \\
3. & Saya berfikiran positif dalam semua keadaan & 3.54 & 0.66 \\
4. & Saya akan bercakap kepada diri bila perlu untuk mengendalikan emosi diri. & 3.43 & 1.06 \\
5. & Saya dapat menaksir sesuatu keadaan yang saya alami & 3.77 & 0.65 \\
6. & Saya dapat mengenali emosi saya & 3.91 & 0.78 \\
7. & Saya memahami maklumat yang dapat mempengaruhi diri saya & 4.14 & 0.73 \\
8. & Saya tahu kesan sikap saya ke atas orang lain & 3.97 & 0.71 \\
9. & Saya sedar bila berlaku komunikasi yang tidak sehaluan & 3.86 & 0.73 \\
\hline
\end{tabular}

\section{Keupayaan Mengurus Emosi Kendiri (Self-regulation)}

Bagi item-item yang telah dibina untuk mengukur domain keupayaan mengurus emosi kendiri (Jadual 7) menunjukkan bahawa skor min tertinggi didapati pada item lapan (8) kemudian diikuti item empat (4) dan item tiga (3). Ini menunjukkan bahawa responden sangat bersetuju responden memiliki keupayaan memujuk diri sendiri untuk menerima sesuatu keadaan (item 8), diikuti dengan responden berfikir mengikut keutamaan sebelum bertindak (item 4) serta responden sedia mengaku kesalahan diri (item 3). Ini menunjukkan bahawa banyaknya responden yang memilih item-item tersebut pada skala sangat bersetuju sehingga skor min yang didapati adalah tinggi berbanding dengan item lainnya. Oleh itu, terdapat juga item skor min terendah daripada item-item lainya pada domain ini iaitu item satu (1), di mana responden tidak pasti samada mereka memiliki keupayaan untuk cepat menetramkan perasaan apabila menghadapi tekanan dalam sesuatu situasi. Ini menunjukkan bahawa majoriti responden memilih pada item satu (1) pada skala tidak pasti samada sehingga nilai skor min yang didapati adalah rendah.

Jadual 7 Taburan min (M) dan sisihan piawai (SP) bagi sub domain keupayaan mengurus emosi kendiri

\begin{tabular}{|c|c|c|c|}
\hline & Item & $\operatorname{Min}(\mathbf{M})$ & Sisihan piawai (SP) \\
\hline 1. & $\begin{array}{l}\text { Saya cepat mententeramkan perasaan apabila saya menghadapi tekanan dalam } \\
\text { sesuatu situasi }\end{array}$ & 3.63 & 0.88 \\
\hline 2. & Saya mampu membuat keputusan dalam keadaan tegang & 3.74 & 0.85 \\
\hline 3. & Saya sedia mengaku kesalahan diri & 4.20 & 0.63 \\
\hline 4. & Saya berfikir mengikut keutamaan sebelum bertindak & 4.23 & 0.73 \\
\hline 5. & Saya berani menyuarakan pandangan jika perlu & 3.71 & 1.12 \\
\hline 6. & Saya dapat menguruskan tekanan yang dialami dengan baik & 3.86 & 0.88 \\
\hline 7. & Saya yakin tindakan yang saya lakukan adalah betul & 3.77 & 0.69 \\
\hline \multirow[t]{2}{*}{8.} & Saya memujuk diri sendiri untuk menerima sesuatu keadaan & 4.80 & 0.49 \\
\hline & Nilai Purata & 3.99 & 1.35 \\
\hline
\end{tabular}




\section{Motivasi Kendiri (Motivation)}

Dalam domain ini, terdapat satu item skor min paling tinggi dibandingkan dengan item-item lainya iaitu item satu (1), di mana responden sangat bersetuju mereka mereka memiliki motivasi kendiri dalam berusaha bersungguh-sungguh untuk mendapatkan sesuatu yang diinginkan (item 1). Manakala item-item lainnya pada domain motivasi kendiri menunjukkan bahawa responden bersetuju dengan item domain tersebut (Jadual 8).

Jadual 8 Taburan min dan sisihan piawai bagi sub domain motivasi kendiri

\begin{tabular}{llcc}
\hline \multicolumn{1}{c}{ Item } & Min (M) & Sisihan Piawai (SP) \\
\hline 1. & $\begin{array}{l}\text { Saya berusaha bersungguh-sungguh untuk mendapatkan sesuatu yang } \\
\text { diinginkan }\end{array}$ & 4.37 & 0.59 \\
2. & Saya cepat berdamai selepas berlaku perselisihan & 4.06 & 0.76 \\
3. & Saya merancang untuk melengkapkan tugasan saya setiap hari & 4.03 & 0.71 \\
4. & Saya tetap melakukan tugasan yang diberikan walaupun ianya tidak menarik & 4.09 & 0.74 \\
5. & Saya berjaya mencapai matlamat walaupun terdapat halangan & 4.09 & 0.85 \\
6. & Saya kerap mencapai keputusan yang memberangsangkan walaupun & 4.00 & 0.73 \\
& menghadapi masalah peribadi & & $\mathbf{0 . 7 3}$ \\
\hline
\end{tabular}

\section{Keupayaan Mengendalikan Hubungan yang Berkesan (Empathy)}

Berdasarkan analisis deskriptif yang telah didapati dalam Jadual 9 didapati item sembilan (9) berada pada tahap skor min tertinggi daripada item lainya kerana banyaknya guru memilih pada skala sangat bersetuju sehingga skor min yang didapati adalah tinggi. Item sembilan (9) ini menunjukkan bahawa responden sangat bersetuju mereka memiliki keupayaan mengendalikan hubungan yang berkesan dengan terdorong untuk membantu seseorang apabila melihat mereka menderita atau dalam kesusahan. Manakala item lima (5) menunjukkan bahawa responden bersetuju mereka cuba menyelesaikan pertelingkahan orang lain iaitu item skor min terendah daripada item lainnya daripada domain ini, kerana banyaknya guru memilih pada item tersebut pada skala bersetuju. Oleh demikian, item lima (5) ini menunjukkan skor min lebih rendah berbanding dengan item sembilan (9).

Jadual 9 Taburan min dan sisihan piawai bagi sub domain keupayaan mengendalikan hubungan yang berkesan

\begin{tabular}{|c|c|c|c|}
\hline & Item & $\operatorname{Min}(\mathbf{M})$ & Sisihan Piawai (SP) \\
\hline 1. & $\begin{array}{l}\text { Saya mampu menguruskan perasaan saya dengan berkesan apabila terdapat } \\
\text { konflik dengan orang lain }\end{array}$ & 3.97 & 0.71 \\
\hline 2. & Saya tahu bila perlu mempertahankan pendapat saya secara berhemah & 3.97 & 0.66 \\
\hline 3. & Saya cuba keluar daripada perselisihan faham & 3.74 & 0.78 \\
\hline 4. & Saya membina kesepakatan dengan orang lain & 4.17 & 0.86 \\
\hline 5. & Saya cuba menyelesaikan pertelingkahan orang lain & 3.54 & 0.91 \\
\hline 6. & Saya mahir berhubung dengan orang lain dengan berkesan & 3.94 & 0.72 \\
\hline 7. & Saya memahami keperluan kawan-kawan & 3.86 & 0.65 \\
\hline 8. & $\begin{array}{l}\text { Saya berjaya membentuk kumpulan sokongan untuk membantu saya } \\
\text { melaksanakan sesuatu tugasan }\end{array}$ & 4.20 & 0.63 \\
\hline 9. & $\begin{array}{l}\text { Saya terdorong untuk membantu seseorang apabila melihat mereka } \\
\text { menderita atau dalam kesusahan }\end{array}$ & 4.43 & 0.69 \\
\hline 10. & Saya prihatin terhadap perasaan orang lain & 4.14 & 0.81 \\
\hline 11. & Saya berjaya membantu kumpulan untuk menguruskan emosi mereka & 3.71 & 0.71 \\
\hline \multirow[t]{2}{*}{12.} & Saya bersedia mendengar masalah yang diceritakan oleh orang lain & 4.23 & 0.77 \\
\hline & Nilai Purata & 3.99 & 0.74 \\
\hline
\end{tabular}

Perhubungan Sosial (Social Skills)

Dalam domain ini, skor min tertinggi didapati pada item dua (2) dan item sembilan (9) berbanding dengan item-item lainnya. Ini bermakna bahawa majoriti guru memilih pada skala sangat bersetuju sehingga mendapati skor min tertinggi pada item mereka memilik perhubungan sosial dengan mereka dapat menerima pendapat orang lain dengan hati terbuka (item 2) dan mereka berjaya mengekalkan hubungan baik bersama kawan-kawan (item 9). Namun terdapat juga item lima (5) yang menunjukkan skor min terendah daripada item-item lain dalam domain ini, di mana majoriti guru memilih pada skala bersetuju sehingga skor min yang didapati agak rendah pada item item tersebut (Jadual 10). 
Jadual 10 Taburan min dan sisihan piawai bagi sub domain perhubungan sosial

\begin{tabular}{clcc}
\hline & \multicolumn{1}{c}{ Item } & Min (M) & Sisihan Piawai (SP) \\
\hline 1. & Saya mudah berkongsi idea atau maklumat jika diperlukan & 4.03 & 0.66 \\
2. & Saya dapat menerima pendapat orang lain dengan hati yang terbuka & 4.26 & 0.61 \\
3. & Saya boleh berkomunikasi dengan baik dengan orang lain & 4.26 & 0.61 \\
4. & Saya mampu mengadakan perbincangan berkumpulan secara berkesan & 4.06 & 0.63 \\
5. & Saya mudah bertolak ansur dengan semua orang & 3.74 & 0.70 \\
6. & Saya berjaya menjadikan orang selesa apabila bergaul dengan saya & 4.11 & 0.79 \\
7. & Saya memberi sokongan dan nasihat kepada mereka yang memerlukan & 4.26 & 0.66 \\
8. & Saya bersedia memimpin sesuatu kumpulan apabila diperlukan & 3.77 & 0.84 \\
9. & Saya berjaya mengekalkan hubungan baik bersama kawan-kawan & 4.26 & 0.61 \\
10. & Saya mampu meyakinkan orang lain dalam sesuatu perkara & 3.94 & 0.64 \\
\hline & Nilai Purata & $\mathbf{4 . 0 7}$ & $\mathbf{0 . 6 8}$ \\
\hline
\end{tabular}

\section{Dapatan Analisis Inferensi Perbezaan Ujian-t}

Dalam menggunakan ujian-t ini ialah untuk membandingkan dua nilai min. Ujian-t merupakan prosedur statistik yang digunakan untuk menyiasat adakah terdapat perbezaan min yang signifikan di antara sampel dengan min populasi. Ujian-t ini juga digunakan untuk membuat generalisasi terhadap populasi yang dikaji. Dapatan kajian ujian-t ini secara umunya dapat menunjukkan bahawa terdapat soalan yang signifikan pada soalan D6 dan E3 kerana terdapat perbezaan nilai min yang ketara daripada guru lelaki dan perempuan berbanding dengan soalan yang ada pada Jadual 11 dan 12. Walau bagaimanapun soalan E9 juga menunjukkan nilai min yang agak ketara di antara guru lelaki dan perempuan. Namun tidak terdapat perbezaan yang signifikan pada aras yang telah ditetapkan iaitu $\mathrm{P} \leq 0.05$.

Jadual 11 Ujian-t keupayaan mengendalikan hubungan yang berkesan berdasarkan jantina

\begin{tabular}{|c|c|c|c|c|c|c|}
\hline Kod & Item & Jantina & $\mathbf{N}$ & Min & Sisihan Piawai & $\begin{array}{l}\text { Signifikan } \\
\mathbf{P}\end{array}$ \\
\hline \multirow[t]{2}{*}{ D1. } & \multirow{2}{*}{$\begin{array}{l}\text { Saya mampu menguruskan perasaan saya } \\
\text { dengan berkesan apabila terdapat konflik } \\
\text { dengan orang lain }\end{array}$} & Lelaki & 17 & 3.88 & 0.78 & \multirow[b]{2}{*}{0.47} \\
\hline & & Perempuan & 18 & 4.06 & 0.63 & \\
\hline \multirow[t]{2}{*}{ D2. } & \multirow{2}{*}{$\begin{array}{l}\text { Saya tahu bila perlu mempertahankan pendapat } \\
\text { saya secara berhemah }\end{array}$} & Lelaki & 17 & 3.88 & 0.60 & \multirow{2}{*}{0.44} \\
\hline & & Perempuan & 18 & 4.06 & 0.72 & \\
\hline \multirow[t]{2}{*}{ D3. } & \multirow[t]{2}{*}{ Saya cuba keluar daripada perselisihan faham } & Lelaki & 17 & 3.59 & 0.71 & \multirow{2}{*}{0.25} \\
\hline & & Perempuan & 18 & 3.89 & 0.83 & \\
\hline \multirow[t]{2}{*}{ D4. } & \multirow[t]{2}{*}{ Saya membina kesepakatan dengan orang lain } & Lelaki & 17 & 4.12 & 0.69 & \multirow{2}{*}{0.72} \\
\hline & & Perempuan & 18 & 4.22 & 1.00 & \\
\hline \multirow[t]{2}{*}{ D5. } & \multirow{2}{*}{$\begin{array}{l}\text { Saya cuba menyelesaikan pertelingkahan orang } \\
\text { lain }\end{array}$} & Lelaki & 17 & 3.41 & 0.71 & \multirow[b]{2}{*}{0.41} \\
\hline & & Perempuan & 18 & 3.67 & 1.08 & \\
\hline \multirow[t]{2}{*}{ D6. } & \multirow{2}{*}{$\begin{array}{l}\text { Saya mahir berhubung dengan orang lain } \\
\text { dengan berkesan }\end{array}$} & Lelaki & 17 & 3.71 & 0.77 & \multirow{2}{*}{$0.05^{*}$} \\
\hline & & Perempuan & 18 & 4.17 & 0.61 & \\
\hline \multirow[t]{2}{*}{ D7. } & \multirow[t]{2}{*}{ Saya memahami keperluan kawan-kawan } & Lelaki & 17 & 3.71 & 0.58 & \multirow{2}{*}{0.18} \\
\hline & & Perempuan & 18 & 4.00 & 0.68 & \\
\hline \multirow[t]{2}{*}{ D8. } & \multirow{2}{*}{$\begin{array}{l}\text { Saya berjaya membentuk kumpulan sokongan } \\
\text { untuk membantu saya melaksanakan sesuatu } \\
\text { tugasan }\end{array}$} & Lelaki & 17 & 4.12 & 0.60 & \multirow[b]{2}{*}{0.46} \\
\hline & & Perempuan & 18 & 4.28 & 0.66 & \\
\hline \multirow[t]{2}{*}{ D9. } & \multirow{2}{*}{$\begin{array}{l}\text { Saya terdorong untuk membantu seseorang } \\
\text { apabila melihat mereka menderita atau dalam } \\
\text { kesusahan }\end{array}$} & Lelaki & 17 & 4.29 & 0.84 & \multirow[b]{2}{*}{0.27} \\
\hline & & Perempuan & 18 & 4.56 & 0.51 & \\
\hline \multirow[t]{2}{*}{ D10. } & \multirow[t]{2}{*}{ Saya prihatin terhadap perasaan orang lain } & Lelaki & 17 & 4.00 & 0.93 & \multirow{2}{*}{0.32} \\
\hline & & Perempuan & 18 & 4.28 & 0.66 & \\
\hline \multirow[t]{2}{*}{ D11. } & Saya berjaya membantu kumpulan untuk & Lelaki & 17 & 3.82 & 0.80 & \multirow{2}{*}{0.38} \\
\hline & menguruskan emosi mereka & Perempuan & 18 & 3.61 & 0.60 & \\
\hline \multirow[t]{2}{*}{ D12. } & Saya bersedia mendengar masalah yang & Lelaki & 17 & 4.18 & 0.88 & 0.70 \\
\hline & diceritakan oleh orang lain & Perempuan & 18 & 4.28 & 0.66 & 0.70 \\
\hline
\end{tabular}

*Signifikan pada $\mathrm{p} \leq 0.05$ 
Jadual 12 Ujian-t perhubungan sosial berdasarkan jantina

\begin{tabular}{|c|c|c|c|c|c|c|}
\hline Kod & Item & Jantina & $\mathbf{N}$ & Min & $\begin{array}{l}\text { Sisihan } \\
\text { Piawai }\end{array}$ & $\underset{\mathbf{P}}{\text { Signifikan }}$ \\
\hline \multirow[t]{2}{*}{ E1. } & \multirow{2}{*}{$\begin{array}{l}\text { Saya mudah berkongsi idea atau maklumat } \\
\text { jika diperlukan }\end{array}$} & Lelaki & 17 & 4.12 & 0.78 & \multirow{2}{*}{0.44} \\
\hline & & Perempuan & 18 & 3.94 & 0.53 & \\
\hline \multirow[t]{2}{*}{ E2. } & \multirow{2}{*}{$\begin{array}{l}\text { Saya dapat menerima pendapat orang lain } \\
\text { dengan hati yang terbuka }\end{array}$} & Lelaki & 17 & 4.18 & 0.63 & \multirow[b]{2}{*}{0.45} \\
\hline & & Perempuan & 18 & 4.33 & 0.59 & \\
\hline \multirow[t]{2}{*}{ E3. } & \multirow{2}{*}{$\begin{array}{l}\text { Saya boleh berkomunikasi dengan baik } \\
\text { dengan orang lain }\end{array}$} & Lelaki & 17 & 4.00 & 0.61 & \multirow{2}{*}{$0.01 *$} \\
\hline & & Perempuan & 18 & 4.50 & 0.51 & \\
\hline \multirow[t]{2}{*}{ E4. } & \multirow{2}{*}{$\begin{array}{l}\text { Saya boleh berkomunikasi dengan baik } \\
\text { dengan orang lain }\end{array}$} & Lelaki & 17 & 3.94 & 0.65 & \multirow{2}{*}{0.30} \\
\hline & & Perempuan & 18 & 4.17 & 0.61 & \\
\hline \multirow[t]{2}{*}{ E5. } & \multirow{2}{*}{$\begin{array}{l}\text { Saya mudah bertolak ansur dengan semua } \\
\text { orang }\end{array}$} & Lelaki & 17 & 3.71 & 0.68 & \multirow{2}{*}{0.76} \\
\hline & & Perempuan & 18 & 3.78 & 0.73 & \\
\hline \multirow[t]{2}{*}{ E6. } & \multirow{2}{*}{$\begin{array}{l}\text { Saya berjaya menjadikan orang selesa } \\
\text { apabila bergaul dengan saya }\end{array}$} & Lelaki & 17 & 3.94 & 0.82 & \multirow{2}{*}{0.21} \\
\hline & & Perempuan & 18 & 4.28 & 0.75 & \\
\hline \multirow[t]{2}{*}{ E7. } & \multirow{2}{*}{$\begin{array}{l}\text { Saya memberi sokongan dan nasihat kepada } \\
\text { mereka yang memerlukan }\end{array}$} & Lelaki & 17 & 4.12 & 0.69 & \multirow{2}{*}{0.22} \\
\hline & & Perempuan & 18 & 4.39 & 0.61 & \\
\hline \multirow[t]{2}{*}{ E8. } & \multirow{2}{*}{$\begin{array}{l}\text { Saya bersedia memimpin sesuatu kumpulan } \\
\text { apabila diperlukan }\end{array}$} & Lelaki & 17 & 3.88 & 0.78 & \multirow{2}{*}{0.45} \\
\hline & & Perempuan & 18 & 3.67 & 0.90 & \\
\hline \multirow[t]{2}{*}{ E9. } & \multirow{2}{*}{$\begin{array}{l}\text { Saya berjaya mengekalkan hubungan baik } \\
\text { bersama kawan-kawan }\end{array}$} & Lelaki & 17 & 4.06 & 0.55 & \multirow{2}{*}{0.06} \\
\hline & & Perempuan & 18 & 4.44 & 0.61 & \\
\hline \multirow{2}{*}{ E10. } & \multirow{2}{*}{$\begin{array}{l}\text { Saya mampu menyakinkan orang lain dalam } \\
\text { sesuatu perkara }\end{array}$} & Lelaki & 17 & 3.94 & 0.66 & \multirow{2}{*}{0.98} \\
\hline & & Perempuan & 18 & 3.94 & 0.63 & \\
\hline
\end{tabular}

*Signifikan pada $\mathrm{p} \leq 0.05$

Dalam bahagian ini, pengkaji juga melihat perbezaan kecerdasan emosi berdasarkan taraf perkahwinan responden. Keputusan ujian-t bagi soalan E3 guru yang sudah berkahwin juga menunjukkan nilai min yang lebih tinggi berbanding dengan guru yang belum berkahwin sehingga terdapat perbezaan yang signifikan kerana terdapat perbezaan min yang ketara di antara taraf perkahwinan guru tersebut. Dalam analisis ujian-t ini, didapati soalan yang terdapat signifikan didapati daripada soalan C1 dan E3 dalam Jadual 13 dan 14 kerana terdapat perbezaan nilai min yang ketara daripada guru yang sudah berkahwin dan guru yang belum berkahwin.

Jadual 13 Ujian-t motivasi kendiri berdasarkan taraf perkahwinan

\begin{tabular}{|c|c|c|c|c|c|c|}
\hline Kod & Item & Taraf Perkahwinan & $\mathbf{N}$ & Min & $\begin{array}{l}\text { Sisihan } \\
\text { Piawai }\end{array}$ & $\begin{array}{c}\text { Signifikan } \\
\mathbf{P}\end{array}$ \\
\hline \multirow[t]{2}{*}{$\mathrm{C} 1$} & \multirow{2}{*}{$\begin{array}{l}\text { Saya berusaha bersungguh-sungguh untuk } \\
\text { mendapatkan sesuatu yang diinginkan }\end{array}$} & Belum kahwin & 18 & 4.11 & 0.58 & \multirow[b]{2}{*}{$0.00 *$} \\
\hline & & Berkahwin & 17 & 4.65 & 0.49 & \\
\hline \multirow[t]{2}{*}{$\mathrm{C} 2$} & \multirow{2}{*}{$\begin{array}{l}\text { Saya cepat berdamai selepas berlaku } \\
\text { perselisihan }\end{array}$} & Belum kahwin & 18 & 4.00 & 0.90 & \multirow[b]{2}{*}{0.65} \\
\hline & & Berkahwin & 17 & 4.12 & 0.60 & \\
\hline \multirow[t]{2}{*}{$\mathrm{C} 3$} & \multirow{2}{*}{$\begin{array}{l}\text { Saya merancang untuk melengkapkan tugasan } \\
\text { saya setiap hari }\end{array}$} & Belum kahwin & 18 & 3.89 & 0.75 & \multirow{2}{*}{0.23} \\
\hline & & Berkahwin & 17 & 4.18 & 0.63 & \\
\hline \multirow[t]{2}{*}{$\mathrm{C} 4$} & \multirow{2}{*}{$\begin{array}{l}\text { Saya tetap melakukan tugasan yang diberikan } \\
\text { walaupun ianya tidak menarik }\end{array}$} & Belum kahwin & 18 & 3.94 & 0.80 & \multirow{2}{*}{0.25} \\
\hline & & Berkahwin & 17 & 4.24 & 0.66 & \\
\hline \multirow[t]{2}{*}{$\mathrm{C} 5$} & \multirow{2}{*}{$\begin{array}{l}\text { Saya berjaya mencapai matlamat walaupun } \\
\text { terdapat halangan }\end{array}$} & Belum kahwin & 18 & 3.83 & 0.92 & \multirow{2}{*}{0.06} \\
\hline & & Berkahwin & 17 & 4.35 & 0.70 & \\
\hline \multirow[t]{2}{*}{ C6 } & \multirow{2}{*}{$\begin{array}{l}\text { Saya kerap mencapai keputusan yang } \\
\text { memberangsangkan walaupun menghadapi } \\
\text { masalah peribadi }\end{array}$} & Belum kahwin & 18 & 3.83 & 0.61 & \multirow{2}{*}{0.16} \\
\hline & & Berkahwin & 17 & 4.18 & 0.80 & \\
\hline
\end{tabular}

*Signifikan pada $\mathrm{p} \leq 0.05$

\subsection{CADANGAN}

Hasil kajian ini merupakan tujuan yang dilakukan terhadap tahap kecerdasan emosi di kalangan guru-guru pelatih di sekolah menegah kejuruan. Oleh itu, berdasarkan daripada dapatan kajian terdapat beberapa cadangan bagi pengkaji-pengkaji lainya yang berminat untuk mendalami aspek yang dikaji. Penyelidikan mencadangkan agar kajian lanjutan perlu dilakukan.

Kajian yang lebih mendalam terhadap tahap kecerdasan emosi dapat dijalankan dengan melibatkan guru-guru pelatih kejuruan di sekolah secara keseluruhan. Justeru, dengan menglibatkan semua sekolah kejuruan di Aceh akan mendapatkan persampelan yang lebih banyak lagi agar maklumat yang lebih dapat di perolehi. Semakin besar saiz sampel maklumat dapat diperolehiakan lebih menyakinkan. 
Penyelidik juga menyarankan agar responden kajian yang dipilih tidak hanya kepada guru-guru pelatih sehaja. Penyelidik seterusnya boleh menjalankan kajian dengan melibatkan palajar untuk membandingkan dengan melihat tahap kecerdasan emosi antara guru pelatih dan pelajar itu sendiri dalam peruses pengajaran dan pembelajaran (P\&P). Kajian-kajian akan datang juga boleh dijalankan untuk melihat kesan kecerdasan emosi (EQ) ke atas kepuasan kerja, prestasi kerja dan tekanan kerja guru-guru pelatih kejuruan.

\subsection{KESIMPULAN}

Berdasarkan dapatan hasil kajian menunjukkan bahawa kecerdasan emosi memainkan peranan penting dalam bidang pendidikan. Kecerdasan emosi harus dilaksanakan dengan sebaik mungkin dalam pencapaian kejayaan pendidikan. Dalam hal ini, guru pelatih harus menekankan aspek kecerdasan emosi dalam melaksanakan tugas masing-masing di sekolah. Pihak sekolah perlu mendidik para pelajar tentang cara yang baik untuk mencapai kecerdasan emosi (EQ) yang tinggi agar dapat mengurus emosi dengan sempurna. Disamping itu, pendidik harus menjadi role model dalam pembinaan kecerdasan emosi (EQ) dengan memberikan contoh sifat-sifat seperti mengambil berat dan bersopan ketika berinteraksi dengan para pelajar.

\section{Rujukan}

A. Anastasi \& Urbina. (1997). Psychological testing. Upper Saddle River, NJ: Prentice Hall.

A. Minhat, Hashim, M., \&Hisyam, M. Persepsi guru-guru bidang teknik dan vokasional sekolah menengah kebangsaan tinggi segamat dalam meningkatkan kecerdasan emosi pelajar: satu kajian kes kualitatif.

A. Shaufie. (2004). Kecerdasan emosi dan kepuasan kerja guru-guru Pendidikan Seni Visual. Tesis sarjana pendidikan yang tidak diterbitkan.Universiti Pendidikan Sultan Idris

C. GIM, C. S., \& Nor. (2012). Kecerdasan Emosi dan Hubungannya dengan Perilaku dan Prestasi Akademik Pelajar Sekolah Menengah di Bachok, Kelantan. Akademika, 82(2), 109-118.

D. Goleman. (1995). Emotional Intelligence at Work Place. New York : Sage Pub.

D. Polit. (2001). Essentials of nursing research: Methods, appraisal and utilisation. (5th ed). Philadelphia, PA: Lippincott.

F.Florance. (2007). Hubungan Tahap Kecerdasan Emosi Demgam Tahap Kepuasan Kerja Dan Tahap Komitmen Kerja Di Kalangan Guru Bimbingan Dan Kaunseling Sekolah Menengah Di Bandaraya Kuching, Sarawak.Universiti Teknologi Malaysia.

H. Ahmad. (2013). Kecerdasan Emosi Dalam Kalangan Guru Sekolah Menengah Teknik Kementerian Pendidikan Malaysia Berdasarkan Model Dulewicz Dan Higg's (Doctoral dissertation, Universiti Tun Hussein Onn Malaysia).

H. Harmain. (2008). Kaitan antara Motivasi Kerja dan Kinerja Guru. Jurnal Pendidikan I. 7(1), 20- 28

H. Mat, H. W., Amira, F., \&Subari, K. (2004). Hubungan Di Antara Kecerdasan Emosi Dengan kepimpinan Bakal Guru Di Kalangan Pelajar Perdana tahun Empat PTV UTM (Doctoral Dissertation, Universiti Teknologi Malaysia).

I. Lestari. (2012). Pengembangan Model Bimbingan Kelompok Dengan Teknik Simulasi Untuk Meningkatkan Kecerdasan Emosi Siswa. Jurnal Bimbingan Konseling, 1(2).

I. Ruisel. (1992). Social intelligence: Conception and methodological problems. StudiaPsychologica. 34(4-5), 281-296.

K. Murphy,.R. \&Davidshofer. (1998). Psychology testing: Principles and application. Boston: 4th Ed. Prentice Hall, Upper Saddle.

M. Majid, K. (1998). Kaedah Penyelidikan Pendidikan. EdisiKeempat.Dewan Bahasa dan Pustaka, Kuala Lumpur.

M. Azhar \& Shamsiah. (2006). Stres dalam kalangan guru pelatih pendidikan universiti teknologi malaysia semasa menjalani latihan mengajar: Fakulti Pendidikan UTM.

M. Idham, Mahamod, Z., Pendidikan, F., Yunus, M. M., \&Yusoff, N. (2010). Profil Kecerdasan Emosi Guru Pelatih Bahasa Mengikut Tahun Pengajian.Online Journal of Language Studies, 10(2), 272-284.

M. Najib, G., AziziHj, Y. \&Yusof. (2002). Kecerdasan emosi: perbandingan pelatih pengurusan ijazah pertama dan ijazah lanjutan. Kajian Jangka Pendek (RMC). UTM. Tidak Diterbitkan.

M. Nasir, M., Azura, Z., \&Mustaffa. (2011). Hubungan Kecerdasan Emosi Dengan Kecekapan Kemahiran Dan Perkembangan Personal Dalam Kalangan GuruGuru Kaunseling Daerah Kulaijaya, Johor (Doctoral dissertation, Universiti Teknologi Malaysia, Faculty of Education).

M. Nazar. (1990). Pengantar Psikologi - Satu Pengenalan Asas Kepada Jiwa Dan Tingkahlaku Manusia. Kuala Lumpur: Dewan Bahasa dan Pustaka.

M. Wedastera, I. W., Dantes, N., \& Yudana. (2013). DeterminasiEkspektasiKarir, Kecerdasan Emosi, Dan Kompetensi Profesional Terhadap Kinerja Guru Smp SeKecamatan Blahbatuh. Jurnal Administrasi Pendidikan, 4(1).

P. Mayer J. D. \& Salovey. (1990). Emotional intelligence. Imagination, Cognition, And Personality, 9, 185-211

R. K. Thorndike. (1920). Intelligence and its uses. Harper's Magazine. 140, 227-335.

R. Rustiana. (2013). Upaya Peningkatan Kecerdasan Emosi Siswa Sekolah Dasar Melalui Pendidikan Jasmani Harmoni. Cakrawala Pendidikan, 5(1).

R.Bar-On \& Parker. (2000). The Handbook Of Emotional Intelligence: Theory, Development, Assessment, And Application At Home, School, And In The Workplace. Jossey-Bass: San Francisco.

W. Masrukin.(2006). PengaruhMotivasi, KepuasanKerja, BudayaOrganisasidanKepimpinanTerhadapPrestasiPegawai. Jurnal Ekobis. 7.2.197-208.

Y. Tahir, \& Boon, Y. Tahap kecerdasan emosi dan hubungannya dengan komitmen guru dalam bekerja dalam kalangan guru mata pelajaran teras tahun enam Journal of Edupress, 1, 187-196.

Z. Majzub, R. M., \& Mahmud. (2009). Kecerdasan Emosi dan Komitmen Pekerjaan dalam Kalangan Pensyarah Universiti di Indonesia (Emotional Quotient and Work Commitment Among Lecturers at An Indonesian University). Jurnal Pendidikan Malaysia, 34(1), 173-186. 